\title{
Gabriel Valansi: neoliberal nights in Buenos Aires
}

$\frac{\text { DAVID WILLIAM FosTER }}{\text { Arizona State University/USA }}$ 


\section{Resumo}

Este estudo examina a fotografia urbana de Gabriel Valansi, cujo trabalho constitui a tentativa de fotografar os efeitos desastrosos do neoliberalismo na Argentina. Ao fotogratfar o "lixo" do neoliberalismo, Valansi demonstra as delocalizações sociais e culturais que tem produzido.

\section{Palavras-chave}

fotografia urbana - Buenos Aires, neoliberalismo na fotografia, lixo na fotografia

\section{Abstract}

This study examines the urban photography of Gabriel Valansi, whose is work is an attempt to interpret the disastrous effects of neoliberalism in Argentina. By photographing the "garbage" of neoliberalism, Valansi demonstras the social and cultural displacement it has produced.

\section{Key words}

photography-urban-Buenos Aires, neoliberalism in photography, garbage in photography 


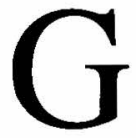

abriel Valansi (b. 1959) is part of a group of eleven Argentine photographers who were featured in a 1999 exhibit, Myths, Dreams, and Realities in Contemporary Argentine

Photography, at the International Center of Photography in New York; he works as both a professor of photography at the University of Buenos Aires and as an artistic advisor at the Museo de Arte Moderno de Buenos Aires. He is also a collaborator with the photography magazine Fotomundo (Buenos Aires, 1966-).

Valansi's work is radically set of from that of the other participants in the ICP exhibit in New York, in the sense that it essentially does not directly feature human figures, that it concentrates on a nocturnal cityscape, and that it is determinedly "anti-aesthetic" in the sense of using not only found objects, but ones that appear to have been abandoned as garbage; junk; no longer useful, damaged and/or trashed objects. Like other photographers in the ICP exhibit, Valansi makes almost exclusive use of black and white images, albeit ones of enormously high resolution that enable very large contact prints. Yet, ambiguity of image is essential to much of Valansi's work, in the sense that, although one can draw a certain global sense from the series, there are individual images that do not immediately lend themselves to objective identification, appearing to fluctuate between impressionistic foregrounded patterns of light and a fragmentation of the outlines of images expected within conventional horizons of familiarity; perhaps some might even find "surreal" appropriate here because of the possibility of perceiving a dreamlike landscape. These qualities are abetted by the nocturnal loss of foreground/background perspective. Although Valansi has also dealt with others themes, he possesses an established identity because of 
his work in the city of Buenos Aires in the deep hours of the night, and it is this cycle of work on which I will concentrate in the present analysis of his photography, in a 1998 series titled Fatherland, which in turn is part of a series of related projects, Zeitgeist (2000) and Epílogo (2000-2001).

To speak of the deep hours of the Porteño night is almost to speak of a No Man's Land, since one might well ask when is there ever a "deep night" in Buenos Aires, when is there a time of the night when the streets are empty of human comings and goings, when businesses are closed, and the intense combination of Argentine sociability and an imperative to live it out on the street declines. To be sure, one of the effects of neoliberalism in Argentina has been to sharpen class divisions and to produce an increasing class of individuals excluded from the sort of prosperity that has made Argentine public life so unique in Latin America — at least, a public life in terms of superavit consumption, the display of cultural accomplishments, and, simply, the enjoyment of the virtues of the flâneur. In a city in which in many sectors (especially the older commercial ones and the prosperous northern tier of neighborhoods that stretch west along the Río de la Plata), night only ends with the first weak light of morning.

This image of the City That Never Sleeps is, in any event, part of the public image of the city, and not one necessarily associated with tourism, because Buenos Aires has never been much of a city of international tourism. There are, certainly, tourists from the interior and tourists from surrounding Latin American countries, not to mention the happenstance tourism of a constituency of business types passing through the capital with a night or so at their disposal to see what the tango etc. are all about. The Porteño barrios, all one hundred of them by legendary count, are not exactly deserted late at night, but the entire city is hardly an extension of the traditional image of the Great White Way of Avenida Corrientes-or of wherever the night life of Corrientes went with the decay of the old downtown and the emergence, with neoliberalism, the emergence of new nuclei of leisure, culture, and entertainment (Puerto Madero, Retiro, La Recoleta, San Telmo, Flores, Palermo Chico, Palermo Viejo, La 
Costanera, Belgrano, and so on, not to mention places outside the city along the river) (one Argentine nightlife in the city, see Gorbato).

Indeed, part of the context of this photography is the fact that neoliberalism cast a pall over the nightlife of the central core (a pall, it must be stressed that began to be felt way back in the $1970 \mathrm{~s}$ before the neoliberal process that began in the early 1990s), not only by encouraging its movement elsewhere, through the construction and promotion of new venues, but also because of first the impoverishment of much of middle-class life neoliberalism brought with it, along with the subsequent profound devastation of overwhelming sectors of Argentine society since the closing months of 2001 . In one sense, any perception of a deep night in at least the old central core of the city is an index of that process, to the extent that it is a direct consequence of it.

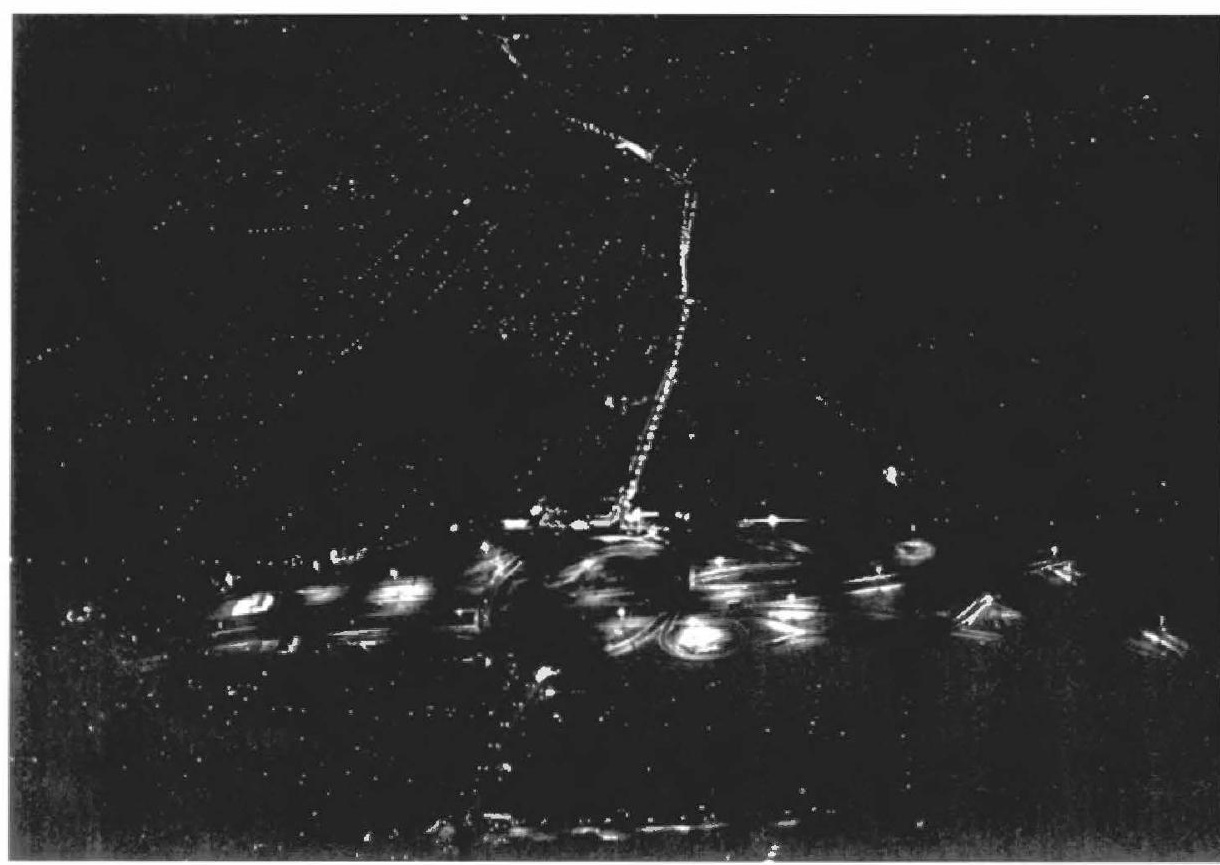

Moreover, Valansi's work, especially what I will be examining here, comes on the cusp of the transition from a still more-orless functioning neoliberalism to what, without putting to fine a point 
on it, must now be identified as something like the Third-Worldization of Argentina: Argentina, and especially the Buenos Aires capital (huge sectors of the country were already increasingly impoverish by neoliberalism well before the last quarter of 2001), is now facing the prospect of having to live like the rest of Latin America. The most immediate manifestation of this is how the illegal workers from countries peripheral to Argentina who poured into Buenos Aires to sustain the underbelly of neoliberal, as portrayed in Adrián Caetano's Dogma-style film Bolivia (2001), have fled the country for their respective homelands: if they are going to starve in the streets, they might as well do so back home; besides, there is the threat that streets are going pretty much to be taken up by starving Argentines.

The series of images analyzed in this study is part of Valansi's 1998 exhibit Fatherland, at the Fotogalería del Teatro San Martín, the most important official cultural space of the Municipality of Buenos Aires. In an interview with Pablo Garber in libroarte.com, Valansi has the following to say about this series of forty photographs:

"Fatherland" es una continuidad de [la] idea de "fines de fiesta", pero a la vez es un registro de lo que yo llamo "los holocaustos encubiertos", que son esos holocaustos que no son mediáticos ni tienen resultados espectaculares, con muerte y desolación. Tienen un armado más sutil, y (entre comillas) son aceptados por el mundo libre, pero en definitiva siguen siendo holocaustos... [La idea de "Fatherland" es] tratar de dar pistas, que tienen que ver con un registro "neutrónico", o sea, que no dejan muertos, ni cráteres, pero que existen. Y como la Argentina vivió sus holocaustos, y vive uno; intenté contar esa historia en "Fatherland".

Valansi makes specific reference to Robert Harris's 1992 novel Fatherland about the holocaust, and this reference provides an enormous resonance to his work, in which he counts on a series of cultural references in the Argentine sociopolitical consciousness. In the first place, Argentina has a special relationship to the Jewish holocaust, not just because Buenos Aires is one of the great Jewish cities of the world (and, therefore, home to many holocaust survivors), but because Argentine enjoyed historically a large German immigrant population, and Adolf Eichmann's arrest there brought world attention to the Nazi influence in Argentina, 
which was not only strong throughout the 1930s and the war, but alsoas is legendarily known-included Argentina becoming, during the first Peronista government (1946-52), a haven for Nazi war criminals like Eichmann (Camarasa, Goñi).

Additionally, the fact that the military regimes of recent decades (1966-73, 1976-83) were overtly modelled along neo-Nazi lines has kept alive a sense of a "fascist tradition" in Argentine (Viñas; The Argentine Right), the slang adjective facho, derived from the more academic fascista, is in daily use to describe an abiding authoritarian mentality and forms of behavior alleged to embody it. Valansi is himself Jewish, and so it is understandable that he would be particularly sensitive to not only a facho strand in the Argentine national ethos ("Lo que este país necesita es una mano dura" [What this country needs is a strong hand] is a common refrain), but as his adjective encubierto signals, the ideological processes by which this mentality is ignored, argued away, hidden, or transformed into something else.

The return to constitutional democracy in Argentina and the much touted trial of the military officers that made up the ruling Juntas, along with many of their most notorious subalterns, were evidence of a shift in the country's institutional climate. Yet the violence of the Menem years (the 1990s) was manifest-all too apparent, for example, in the virtually officially sanctioned persecution of journalists; the also virtually officially sanctioned depredations of corruption, by agents of the government and segments of the business and banking communities and their shared cohorts; and the economic upheaval wrecked by neoliberalism may be interpreted as the sort of "hidden holocaust" that Valansi has in mind. It was hidden not that people did not know that violence was taking, but rather because the mass of its victims-the common folk-were never consistently recognized as such. Indeed, the synergetic effects of unchecked neoliberalism and flagrant corruption have brought the country to a point of stagnation, exhaustion, and despair that are quite unprecedented. It is not that Argentina is alone in Latin America in terms of major social problems, but it is far easier to point to the photographable consequences of public violence in, say, Colombia than it is to the hidden violence in Argentina. 
But yet Valansi's point would be that that violence is now not quite so hidden. Others may photograph the evidence of that violence in terms of the victims of street crime that has turned the once absolutely safe Buenos Aires into a place as dangerous as any other metropolitan center. There was for long the curious way in which Buenos Aires was always marvelously safe despite the repressive acts of what the current president, Eduardo Luis Duhalde once called the "terrorist state," and this was not just because of the facile belief that fascism makes for safe streets. Others may also photograph the creeping way in which a megacity with narrow streets and many buildings now over a century old can, all of a sudden, began to show clear signs of decay; and at that, even at the height of the prosperity induced by neoliberalism in the early 1990s, public buildings were never very well maintained.

Valansi's photography takes a much more subtle approach to the recording of social reality in the context of the ongoing holocaust of economic violence. In the first place, human figures are absent from his work. There is the standing belief that "real" photography, with the exception of utilitarian photography that aims no more than to provide a record of a space, a building, a device, or a situation, is artistic to the extent that includes a human presence. The one exception that is generally accepted is nature photography, in which the beauty of flora and fauna may be prized to the extent that man-at least, modern man-is absent, since civilization is usually viewed, as is trenchantly apparent in denunciatory

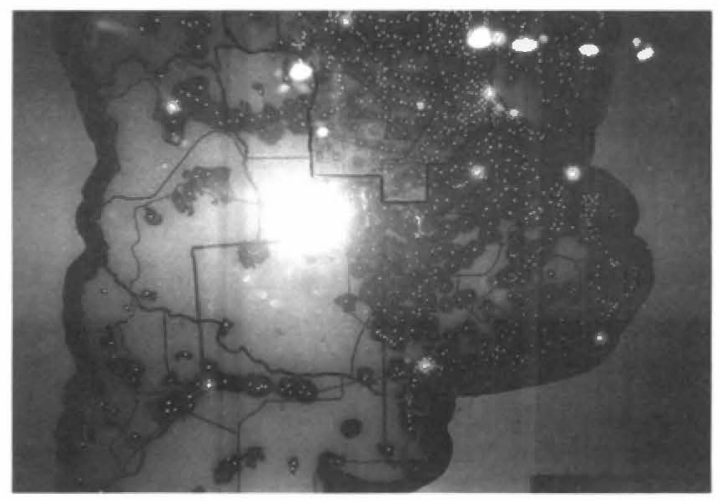


ecophotography of the sort practiced by the Brazilian Sebastião Salgado, as destructive of nature and the environment: this belief extends far beyond those in the ecological movement, such as to make even the kitchiest images of the landscape or animal life valued for their decorative and presumedly soothing qualities.

But the exclusion of human figures, especially in the built environment of the city, where the "human interest" presence is understood to give meaning to, often casually, urban backdrops. Certainly, there are urban monuments that have merited their own interpretive photographic record, especially ones that are related to major historical, social, and political events (e.g., the veritable kitschification of the Statue of Liberty, the Golden Gate Bridge, anddare I say it? - the Twin Towers of the World Trade Center). But just as a cliche of grade-B sci-fi movies is the eery sensation of the city of the disappearance of human figures as a metaphoric harbinger for the disappearance from the planet of the human species, any photograph of a segment of urban reality in which human beings are not present is sensed to be at best nostalgic ("this was someplace where people once lived") or disturbingly dehumanized ("where are the people who [must] live here?"). The fact that the built human environment was built by human beings to serve specific human needs, while also being adapted, expropriated, reclaimed for complementary and supplementary needs is both what may make some viewers distribute by the absence of human beings who depend on the built environment for livelihood and survival and what may

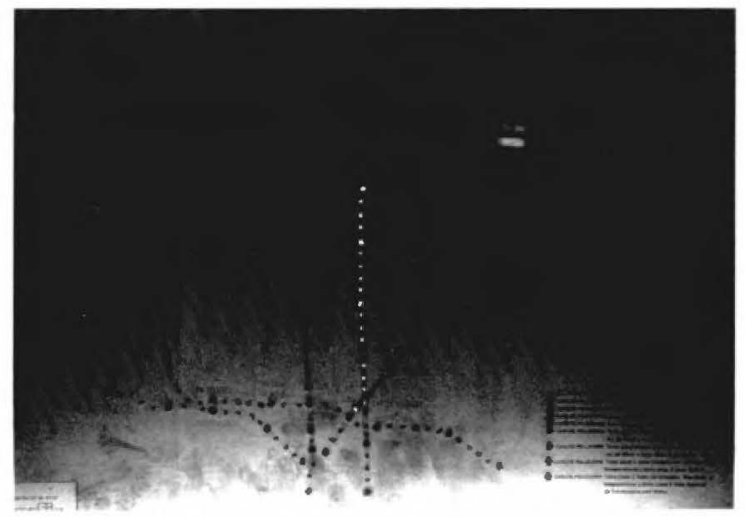


make some viewers experience feelings of dehumanization: the absence of human beings would seem to negate the need for the building, and many routinely feel that abandoned buildings and sites need to be recycled, rebuilt, or cleared because they allegedly constitute eyesores, if not places of and for crime and assorted delinquency. It is, therefore, rather difficult to be convincing as regards a poetry of vacancy or the absence of human figures.

Yet, there is a poetics to be associated with viewing such spaces, to the extent that there is a fairly evident point to be made about their configuration as a consequence of the momentarily or perhaps even permanently absent humanity: archeologists routinely draw important conclusions about the nature of human life from the ruins left behind by disappeared people, and a sort of human geography allows us to view an urban scape and speculate as to features about people who may live there, both in terms of how they have built that environment to meet their needs, or how the already built environment shapes their understanding and satisfaction of their needs. And there is another way in which we can view the sort of vacant spaces being discussed here, which is in terms of why they are vacant. That is, in a version of the sci-fi films mentioned above, where vacancy has occurred because of some monstrous catastrophe of space aliens, a mystery virus, or whatever, something has caused these spaces to become vacant.

In the case of night scenes, certainly the vacancy occurs because of the routine abandonment of certain spaces as part of the established or conventional rhythm of social life. However, such vacancy is relative, and in the case of a city like Buenos Aires, where there has customarily been a greater visibility of people out and about at night, with concomitantly, a larger number of so called night spots, one of the interests in photographying night becomes as much this greater utilization of public spaces at night as it is, through counterpoint, a perception of the decline of such utilization.

This is, precisely, what is at issue, at least in an initial approximation to them, in the bulk of the entries in the Fatherland exhibit, and I will now turn to these images in order to demonstrate how they constitute an interpretation of the effects of neoliberalism 
on Argentina-as viewed through the economically and sociopolitical centralizing city of Buenos Aires-and how that liberalism constitutes a hidden holocaust and in a society for which "the party is over" (hence, the name Epílogo for a follow-up series to Fatherland).

Valansi's opening image, the one that is the signature piece for the exhibition, is intriguingly mysterious. From a distance, the image appears to be an impressionistic pattern consisting of a dark background with a foregrounded pattern of glowing white spots. A line of smaller white spots snakes up the image vertically and elbows off to the left, only to return to a perpendicular position as it bleeds off the top of the image. Around this central line smaller clusters of dots organize themselves into a combination of rectangles and random clusters. Closer inspection, however, reveals that the spots are the lights that one would typically associate with a nighttime cityscape: high intensive street lights (or, perhaps a combination of high intensity and medium intensity ones), lighted billboards, car lights (note, however, that it has only been the enormous increase in car traffic in the city that has brought the mandatory use of high beams), and some buildings. The pattern that emerges on the basis of the discovery that this is a nighttime cityscape is that of a part of the city in which a freeway, with its looping access ramps) constitutes the horizontal axis of the image, with an exit to an important arterial that snakes up the image and bleeds of its top margin. The rectangular patterns are formed by lower intensity lights that border major and minor streets and mark the parameters of city blocks.

The relative irregularity of these patterns would seem to suggest that this is the central core of the city, as befits a city whose definitive foundation dates from 1580 (there was an abandoned attempt to found Buenos Aires in 1536), while a long way from being as randomly nongeometric as medieval European cities, is made up of relatively small blocks that are often poorly lighted, whose geometry is often interrupted by diagonals, alleyways, and bisecting and irregularly drawn boulevards; the phenomenon of "streets that don't

1. By central core one refers to a combination of the sector descendent from the original settlements, the main administrative and financial installations, and 
go through" is frequent in the central core. ' Since the rectangles in the image are not punctuated very much by other points of light, one can believe that the time is very late. That is, there are few white spots that can be attributed to the lights of houses of businesses located within the blocks.

I am speaking in such detail about this perceived layout of the city, as the inaugural image makes a defining statement of the sequence of photographs as a whole. And that is done in terms of the juxtaposition between the freeway and the necessarily older arterial that feeds into it: older because it is likely the arterial was there before the freeway, especially in view of its irregular line. ${ }^{2}$ There are not many freeways in Buenos Aires (just as there are, generally speaking, not many in all of Latin America): they are too expensive to build and maintain, and their installation is too disruptive of a residential, commercial, and industrial life that is often precarious enough without the effects of massive relocation. ${ }^{3}$ Although there are some design and execution problems with the freeways the military imposed on the city beginning in the 1970 s-indeed, it is easy to believe that the freeways could only have been built by a tyrannical regime powerful enough to ignore common needs)-there is no

historically, the residential neighborhoods that historically served these installations. This would be, in very broad terms, the part of Buenos Aires east of the Entre Ríos/Callao avenue (all streets in Buenos Aires change namegoing north and south of Rivadavia, which, by extending east-west from one end of the city, divides it into two dominant spheres; in general terms, the city tends to be more prosperous on the northern side of Rivadavia.

2. Valansi has informed me in a personal communication (August 22, 2002) that the arterial is the Avenida 9 de Julio, which crosses the city, perpendicular to Rivadavia, from north to south (it is the one street that does not change name as it crosses Rivadavia). Valansi says that the image was taken from a plane as it approached the downtown Jorge Newberry airport, although he does not recall whether the segment is north or south of Rivadavia; because of its jagged line, it is probably the southern section, which shifts somewhat east of its basically straight-line path to avoid the Peronist landmark building, Obras Sociales (in its northward march, the Avenida shifts very slightly to avoid an equally important landmark for the Argentine social elite, the palace that houses the French Embassy).

3. As of this writing, residents, mostly low-income, in the Mexico City periphery of San Salvador Atenco have prevailed against the plans of the Fox government to build a hugh new international airport there, a project equally disruptive as that of freeway construction. 
question that these roads have been important for the commercial and industrial life of the city, especially in providing rapid access to the Ezeiza international airport, some twenty miles west of the downtown and previously extremely difficult to get to because the traveler departing from the administrative and financial center had to cross the entire city before reaching the two-lane highway that completed the journey to Ezeiza.

Moreover, confirming the proposition that if you build freeways, the cars will come, the three - or four - fold increase in cars in Buenos Aires that came with neoliberalism would have been virtually impossible without the freeway, and the same is true of the residential development of the suburbs west, northwest and southwest of the city that have been prized as part of the American lifestyle whose incorporation-or implantation-was crucial to neoliberalism. Thus, where this image becomes eloquent is in juxtaposing the traditional arterial, which owes its irregular line to having developed in conformance to geographic irregularities and the gradual urban growth of the city, and the modern freeway which cuts a brutal swath across the cityscape, creating massive disruptions and dislocations and often constituting an abiding environmental problem for the neighborhoods through which it passes: although it is possible to control fumes and noise, as many European and American cities assure they are doing with their freeway networks, the increase in traffic and concomitant traffic-related accidents is not something that can be controlled, since, quite the contrary, an increase in traffic is exactly what the freeway is meant to produce (one of the best examinations of the urban consequences of freeways is Davis's discussion of the issues surrounding the creation of freeways in that paradigm of the freewayed city, Los Angeles).

It is appropriate that Valansi use an image of the freeway as the signature piece of the Fatherland exhibit: other manifestations of neoliberalism proper (i.e., the system specifically imposed at the beginning of the Menem government in the early 1990s, as dictated by the Reagan administration and the International Monetary Fund) can rapidly disappear, as they have already begun to do so-i.e., specialty stores importing foreign goods. But the freeway is virtually a permanent monument, and short of falling so much into disrepair 
that it can no longer be used, it is unlikely that it will disappear merely because the economic system of which it is a part disappears. Moreover, the freeways were actually part of a promodernization project that goes back to the military regimes, well before neoliberalism proper, but yet integral to the sort of ruthless capitalism, mediated by staggering corruption, that those regimes supported and that, under the aegis of constitutional democracy, the Menem government legitimated. ${ }^{4}$

The large-scale image of the city of the anchor photograph of Fatherland is complemented by several other views of the urban landscape in general. There is one, for example, that is a map of the mid-section of the country, one that is also built on lights indicating population concentrations (I do not know if this is a formal demographic representation, or if is a figurative one created by Valansi). The result is to show the enormous preponderance of the Provincia of Buenos Aires and, within it, of the city of Buenos Aires: if Argentina is accused of living with its back to the rest of Latin America, the Province of Buenos Aires lives with its back to the rest of Argentina, and the city of Buenos Aires lives with its back to the rest of the Province and the rest of the country and the rest of the continent. There is a long history of struggle relating to the role of Buenos Aires. The creation of La Plata in 1880 to serve as a decentralized capital of the Province was meant to address the power imbalance between Buenos Aires and the rest of the Province of Buenos Aires, and the designation of Buenos Aires in 1996 as an autonomous Federal Capital intended to separate out the responsibility of the city for its own administration, independent from the federal budget off of which it had grown accustomed to living. In 1940 the social essayist Ezequiel Martínez Estrada published La cabeza de Goliath, in which he posited a master trope for the relationship between Buenos Aires and the rest o the country, that of the enormous head and the feeble

4. There are now some "permanently" uncompleted parts of the freeway system as originally conceived in Buenos Aires, which speaks to a combination of poor planning and underfunding. Moreover, there are areas under the freeways, especially on the poor south side, that have been taken over as refuges for the homeless. 
body. This trope became all the more apparent with recent economic processes, because so much of the rest of the country experienced growing impoverishment alongside the overwhelming concentration of capital in Buenos Aires.

The migration of cabecitas negras from outlying provinces, mostly to the north, begun during the Peronista period and under very different ideological, social, and economic circumstances nevertheless continued and intensified because there was no work to be had except in Buenos Aires, and it was complemented by the aforementioned influx of cabecitas negras from surrounding Latin American countries. ${ }^{5}$ In Valansi's photograph, the all-roads-leadto-Rome concentration of lights in the Buenos Aires area is an echo of the liberalization of the metaphor, in the sense that it duplicates the very real way in which the railroad system of the nineteenthcentury liberal economy, which was designed to carry Argentine exports to the port for shipment to Europe and the importation of European luxury items to the mansions of the city and the rural estates of the wealthy exploiters/producers of those exports (the history of this development is told by Scobie). These lights are, in turn, complemented by the lights of other urban concentrations of the country, such as the subsidiary cities of Córdoba, Mendoza, Rosario.

However, the photograph is very effectively dominated by the reflection, in dead center, of the flash of the photographer's camera. This dead-centering of the flash has no function in terms of artistic symmetry. Rather, it is meant to correlate with - and predominate over - the lights of Buenos Aires and other urban, commercial, and financial centers, as the constituting punctum of the photographer's interpretation, by falling on the northern part of the Province of La Pampa, partially blotting out the spot on the map Valansi uses where the capital city of La Rosa is located. The Province of La Pampa is the Argentine heartland, and its name is the very

5. Cabecita negra literally means "black head" and refers to the dark complection (from the point of view of European-like Buenos Aires) of rural Argentines of indigenous origins; by extension, it also refers to Latin Americans from other countries, especially poorer ones. Thus, the term, in addition to being a racial slur, has ethnic and socio-economic overtones. 
geographic designation that is most famously associated with the land of Argentina, the vast Pampa that supports its historically most important and prosperous industry, cattle-ranching. Interestingly enough, in the schematic map of Argentina that I have at hand, prepared by the Instituto Geográfico Militar, this area is represented as minimally settled (Atlas de la República Argentina). This is true literally in the sense that it is part of a network of small towns that network the vast cattle ranches of this and the other provinces of the industry, La Pampa, Córdoba, Santa Fe, and Buenos Aires. In this sense, there is the evocation of the symbiosis linking Buenos Aires and the cattle ranches that is integral to so much of Argentine social and political history.
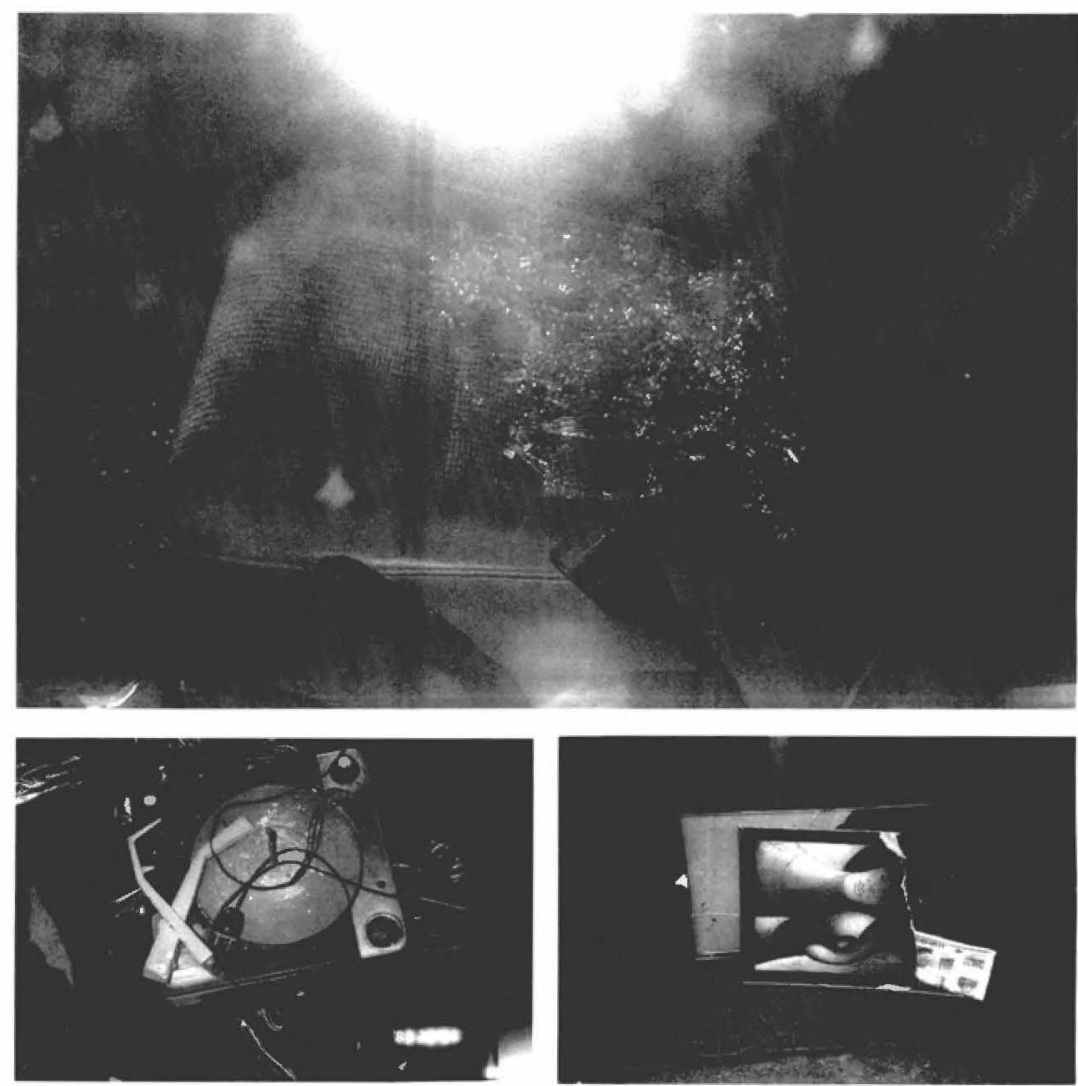
But there is another way of reading this image, and that is in terms of the devastation of the countryside by the neoliberal concentration of the metropolis and its satellite cities. In the case of the old liberal economy, there was something like a balanced exchange between the countryside and the port city (or port cities, since Rosario, up-river from Buenos Aires, is also a major shipping port): the countryside produce the export wealth, a percentage of which Buenos Aires got as the customs port; the imports this wealth bought was distributed between the wealthy estancias (the cattle ranches) and the city that served their interests. Indeed, it was customary for the cattle barons to have, in addition to their often quite magnificent country mansions [Nuestras estancias], fancy apartments or equally magnificent mansions in the city. The large-scale development of industry spurred by Perón beginning in the late 1940s upset this balance, beginning with the transfer from rural areas (which included large numbers from the indigenous north) to the city of cheap labor (the cabecitas negras), which was later, in the 1990s, supplemented by the influx of cheap laborers from surrounding countries. It upset the balance because it represented only a minimal transfer for wealth back to the provinces: Buenos Aires became more and more of a universe unto itself, further exacerbating the trend that Martínez Estrada had perceive more almost a decade before with his essay. The consequence has been the unchecked impoverishment of the countryside, so much so that despite any previous perception that Latin America really began with Argentina's borders with its neighbors, one could well maintain that it really begins with the Avenida General Paz that wraps around the southwestern, western, and northwestern edge of the city (the south is bordered by the Riachuelo tributary and ship canal, while the north and east are bordered by the Río de la Plata).

A third image continues the transposition of geographic images into photography for the purpose of imagining the centers of symbolic and real control of Argentine society. Just as the train system funnels into Buenos Aires and fans out from Buenos Aires as part of the historical control of the entire country by the port city, the subway system, whose origins date back to the heyday of Argentine prosperity 
at the beginning of the twentieth century (the first line was opened in 1910), shows the same sort of pattern as regards the executive and financial center of the city vis-à-vis the outlying neighborhoods (see Barreda for an interesting series of photographs on the Argentina subway system). Ground zero of the city, on the edge of the old colonial core, is the Casa Rosada, the Argentine Government House; directly to the north extends La City, the financial district. These are the areas served by the original subway system, and the original line (Línea A, which runs under Avenida Rivadavia, the principal avenue of the city) ends bneath and behind the Casa Rosada; there are two more lines (D and E) that branch out from a station close to that terminus, and there is a line that runs parallel to A (B) along Avenida Corrientes; it is anchored at Correos, the nineteenth-century palatial main office building of the mail service (Correos is one of the major edifices of the oligarchic liberalism of the late nineteenth century; the Casa Rosada incorporates the previous seat of the mail service and goes back to the colonial period of the eighteenth century). There is also a perpendicular line (E) that links two of the three main railroad stations (Retiro on the north end-actually a cluster of three stations - and Constitución to the south; the third rail station, Miserere-also known as Once-is the western terminus of the A line). Currently, a sixth line $(\mathrm{H})$ is being built west of the city. When completed, it will be the only line to exist outside center of real and symbolic power of the city.

Thus, this image too records the organizaton of power in the Fatherland. But there is another dimension to this photograph: Valansi has rescued an infromation board from the Pasteur station of the Corrientes line (Línea $\mathrm{C}$ ). This was the station in the heart of the old Jewish quarter of Once just blocks from the seat of the AMIA (Asociación Mutialista Israelí-Argentina) which was bombed by terrorists in July 1994. The death and destruction of that bombing was extensive, and one small trace of the devastation of that blast is the fact that the sign board's contacts were frozen in their indication of the Pasteur station; it was years before the sign board was ever repaired.

The three photographs I have discussed so far are related to abstract social interpretations that rely on essentially geometric images of the city. However, the photographs that follow in the exhibition 
are more immediately personalized: whereas the first images represent overarching questions of economic and political control, the remaining images reflect the actions and circumstances of specific human beings. While these agents are not directly recorded by the photographs, their actions and circumstances are: what we see is the detritus of human lives as they pass through the neoliberal system. I have used the word detritus because these images capture in a metonymic function the processes of an economic system that produces waste, garbage, leftovers, material excrescences, discarded and disposed of items from daily life as it is impacted by the system. Like an archeologist reconstructing the nature and dynamics of a society through its garbage-and so much of what archeologists do dig up is the garbage of the past-Valansi the photographer is analyzing the garbage of present-day Argentina. This detritus appears on the streets at night, as what is replaced each day by the fundamental capitalist principle of programmed obsolescence is discarded to make way for the new, which in this case are the particular fruits of participation in the globalized system of imported goods or, at lest, goods that are a step up in some way by comparison to what is being discarded. In a crowded modern city, this is garbage that appears on the sidewalks at night, to be carted off by the garbage service-although, with the economic debacle currently gripping the nation and the city of Buenos Aires, there is not only less garbage on the street, but what there is is exhaustively combed by organized networks of garbage pickers (the cartoneros), cousins to those who sift through the metropolitan garbage dumps of the world. Garbage is here a metonymy of the system because it is a byproduct of it, both in terms of the nature of what constitutes garbage, but also how garbage is recycled by a society. Finally, since garbage is something that appears at night, in part because much of it is what is generated by human activity and commerce in the course of the "business hours" of the day, it is in the Porteño night that Valansi must do the analytical work of his photography. ${ }^{6}$

6. Valansi has shared with me the delightful fact that these photographs were made with a Kyocera camera that he rescued from being thown in the garbage. 


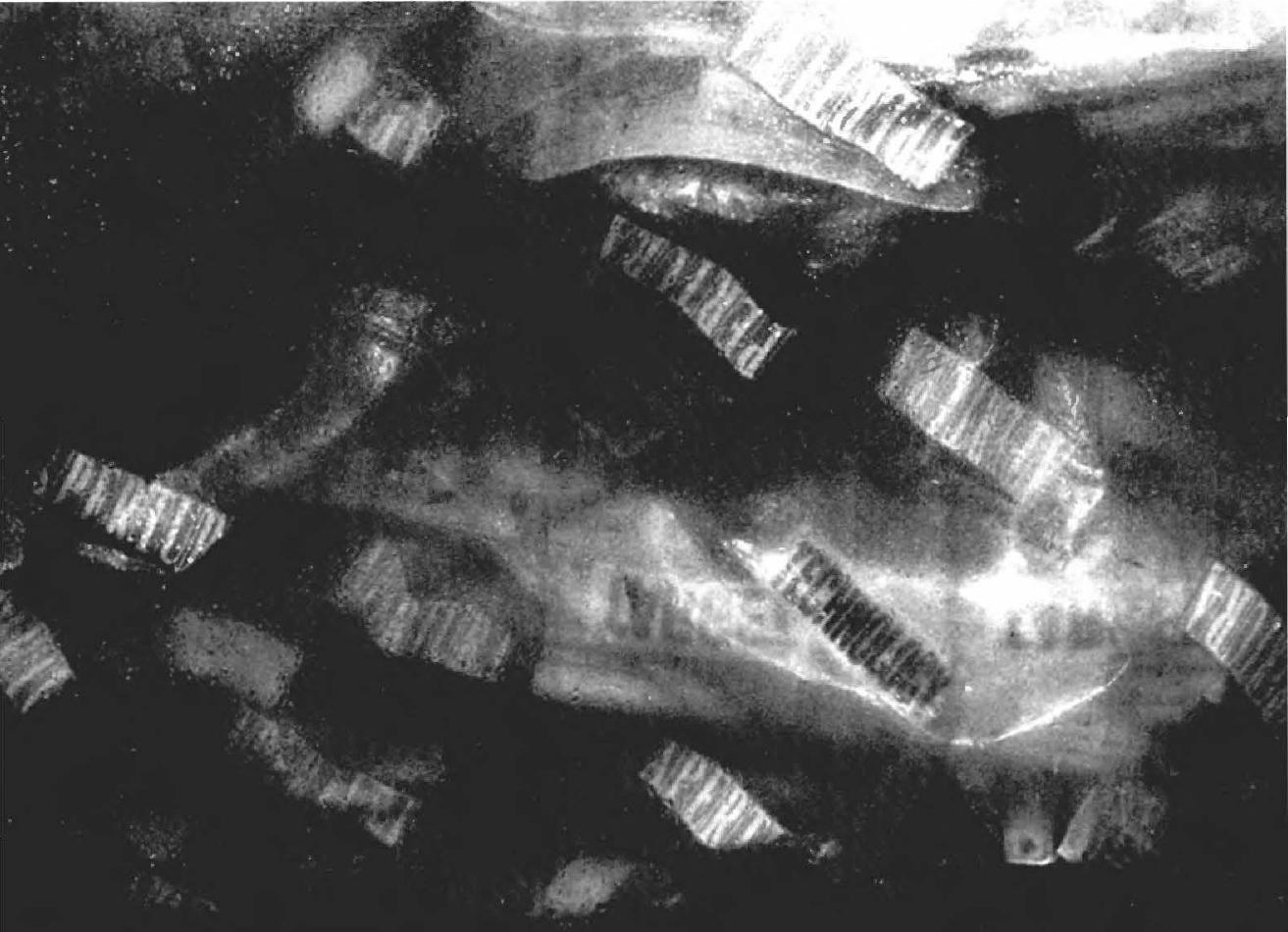

Let us now examine some major exhibits of this work.

One of the most obvious faces of the neoliberalist economy was the enormous number of new businesses that opened. Buenos Aires has always been an intensely commercial city, one that prides itself on the number of boutiques, bookstores, restaurants, bars (the city has some of the best bar life in the world, with "bar" being understood here in a far broader sense than the usually American use of the word: perhaps a combination of British pub and French café begins to capture this great Porteño social institution), along with myriad specialty shops. Not only were new businesses opened, which often meant recycling spaces, some with a measure of elegance. This is the case of the bookstore that opened in one of old art deco movie houses, the Cine Gran Splendid, with the stage area used as a café. Tax credits were available for the modernizing and refurbishing of older locales, which for some habitues meant, regrettably, the loss of the early twentieth-century patina that was their most attractive feature.

As a consequence of all this commercial movement, signs announcing the (re)opening of businesses were common, icons of 
the attainment of neoliberal nirvana. Valansi's image of crumpled APERTURA ("Opening") banners can be read in two ways (there is also one banner, in English, that reads TECHNOLOGY and, beneath it, a semitransparent one that seems to read TARGET backwards, also in English). But the APERTURA banners, as crumpled trash, signal the opening of yet one other business, one in which TARGET and TECHNOLOGY are somehow involved: certainly, technology, since one of the substantial incursions of new businesses involved those that were technologically based, such as computers and telecommunications, along with a host of others: every place in town seemed overnight to adopt electronic cash registers in place of longstanding primitive ways of keep track of bills and tabs, including simply the reliance on a serving person's memory.

Yet, there is another way of reading this crumpled heap, and that is in terms of the geometrically increasing number of businesses, especially the trendy ones that came with globalization, that began to go out of business some time before the definitive collapse of neoliberalism at the end of 2001. The decline had been of concern for something like two years, during which the maintenance of parity of the Argentine peso with the U.S. dollar became more and more a science-fiction scenario. Thus, trash is generated in two ways: there is the trash of the establishment of business (which might include the packing of the products that will be offered for sale or, in a previous stage, the debris of the remodelling of a space for the new business), and there is the trash of a business that has gone belly up: not the products themselves, but the junked material infrastructur of the business operations.

One of the images I have found most eloquent is of an abandoned record player. It looks very much like a Philco-type portable unit from the 1950s or early 1960 s, one designed to play a stack of 33 1/3 LPs; the cord shows that it was of Argentine manufacture, since the plug consists of the old round prongs that were made for connecting to 220 volt sources. This is certainly an outdated piece of equipment by at least two generations: the replacement of records in general by tape cassettes, and the replacement of tape cassettes by CDs; moreover, the newer equipment is likely to have three-prong 
plus (flat ones in a triangular pattern) to permit the incorporation of the ground connection that is especially important at the level of 220 volts. Such equipment was manufactured by Argentine companies, since during the period from which it likely dates imports were strictly controlled and direct-from Europe and U.S. products were not commonly found, and those were brought in, at least from the U.S., had to be adapted to the local current or used with clunky power transformers. In recent decades, however, and most assuredly during the 1990s, the market has been flooded by import products, which in the area of electronics has meant particularly Japanese ones, but equipment specifically designed for the Argentine user, and there is much to be said about the details concerning marketing of computers and television sets. Suffice it to say that, for the contextualization of this image, the marketing of the latest generation of electronic products in Argentina, including the calculations of planned obsolescence, have rendered absolutely disposable the equipment that reaches back to the period of this phonograph. Not only do the newer products offer the latest technology, but they offer prices that have made it possible for consumers to get rid of the equipment they were holding on to, not because of any nostalgic attachment, but because until neoliberalism it was for many simply not possible to replace older equipment and to have economically viable access to newer technologies.

One of the interesting details of this photograph is the disposition of the two mechanical arms that were part of the playing of the record, the stabilizing arm that held the stack of records level and the tone arm that held the stylus that actually read the grooves of the record. The arms are crossed in an X, as though suggesting the annulment of the usefulness/usability of the equipment, while the tone arm is positioned as though uselessly playing the record-less turntable: there are no more records like this to play.

One of the major items discarded during the periods of $l a$ plata dulce (the sweet money) and neoliberalism were cars. Those who knew Argentina in the 1960 s will recall that the city was filled with ancient cars, many of them venerable Mercedes-Benz that were bought after the war from Germany. There were cars of somewhat 
dubious quality made by local subsidiaries of American companies and European ones, and the tin can-like Citroën, jokingly said to lend itself to disassembly in a matter of minutes with a can-opener, was ubiquitous. There were some American imports, but it was generally assumed that they belong to Embassy personnel or someone of their ilk. The tripling plus of the numbers of cars clogging the streets of the city in the 1990s meant not just increasing the number of cars geometrically, but getting rid of the old cars as unworthy of the new First-World image it was the order of the day to promote.

Valansi's images of a smashed and, apparently, abandoned figure this dimension of the new economy. One image is of the seat of a car-one that seems not all that old, because it is possible to discern the female buckle of the seat-belt installation; the seat is covered with the smashed-in glass from one of the windows. Another image shows the open trunk, with some sort of garbage dumped into it. Even if the car(s) in question may not be exactly the ancient ones replaced by the influx of new vehicles in the late 1970s and the past decade, they symbolize the "luxury" of the trashing and abandonment of vehicles in a product-replacement/substitution economy. Cars are the quintessential icon of modernity and of personal and collective prosperity, and the greater the complexity of the modern(ized) economy, the more vital cars are as instruments of the mobility that economy requires for both the production and the consumption of goods.

Finally, one last image, that of a discarded painting (likely to be a reproduction); two halves of the piece of art are piled on top of one another, back-to-back, with half of the image exposed. Tucked between the two torn halves is a newspaper. Newspapers are of the day, to be read and discarded; as the saying goes, there is nothing as trite as yesterday's news. By contrast art, even that art that is preserved in inexpensive and mass-produced reproductions, is supposed to be eternal; yet here both are consigned to the same rubbish heap. It is as though the actuality of First-World Argentina, which is what the newspaper would be reporting on (whether favorably or critically) brought down to its own level great works of art, which is the theme of the banalization of culture by neoliberalism and the replacement 
of the self-reflective nature of art by the superficial nowness in which the reporting of mass-society newspapers were all that one need to know: both newspaper and art work are being discarded, but the newspaper is intact, while it is the painting that is torn asunder.

Valansi's photographs in Fatherland are highly effective interpretations of the dark side of recent socio-economic processes in Argentina as viewed through the hardly noticed detritus of the night. Not only does one not customarily scrutinize garbage (except for the aforementioned and highly organized garbage pickers that now make up a booming occupation in Buenos Aires), but it remains essentially unseen: dumped in the street or along the sidewalk at night, the citizen simply assumes that it will be gone by the morning, taken somewhere out of sight, so that no more than a passing notice need ever be taken of machine produced excrement of modernity.

One closing note: Valansi gives his exposition a title in English. He has claimed, in the interview from which the quote at this beginning of this study is drawn, that the title is taken from a novel (by Robert Harris) dealing with the triumph of Naziism. But the Nazi inflection would suggest the German Vaterland. The use of Fatherland in English suggests the resonance of American society, since understanding the complicity of, first, the military dictatorships and subsequently the new democratic governments with American financial interests is crucial to an adequate interpretation of current degradation of Argentine national life.

\section{Bibliografia}

DEUTSCH, S. McGee and DOLKART, R. H. 1993. The Argentine Right; Its History and Intellectual Origins, 1910 to the Present. Washington, D.C.: Scholarly Resources.

ATLAS DE LA REPÚBLICA ARGENTINA; incluye reseñas geográficas y cuadro estadístico. 1992. Buenos Aires: Librería "El Ateneo" Editorial.

BARREDA, Fabiana. 1998. La ciudad subterránea. Buenos Aires: Magna Publicidad. 
CAMARASA, Jorge A. 1995. Odessa al sur: la Argentina como refugio de nazis y criminales de guerra. 2.ed. Buenos Aires: Planeta.

DAVIS, Mike. 1990. City of Quartz; Excavating the Future in Los Angeles. Photographs by Robert Morrow. London: Verso.

DUHALDE, Eduardo Luis. 1983. El estado terrorista argentino. 1.ed. Barcelona: Argos Vergara.

GARBER, Pablo. «Gabriel Valansi.» libroarte.com. <http:// www.leedor.com/fotografía/gabrielvalansi.shtml

GOÑI, Uki. 2002. The Real Odessa: How Perón Brought the Nazi War Criminals to Argentina. London: Granata Books.

GORBATO, V. 1997. Noche tras noche. Buenos Aires: Editorial Atlántida.

NUESTRAS ESTANCIAS. 1968. Argentine ranches. Cincuenta estacias representativas de la República Argentina. Buenos Aires: Casa Pardo.

SCOBIE, James R. 1974. Buenos Aires: Plaza to Suburb, 1870-1910. New York: Oxford UP.

VIÑAS, David. 1977. Qué es el fascismo en Latinoamérica. Barcelona: Editorial de La Gaya Ciencia. 